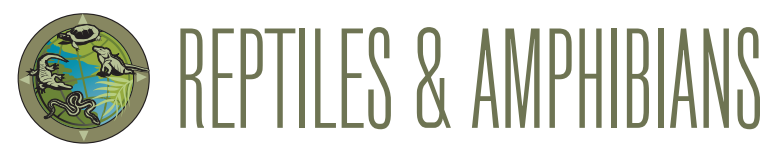

\title{
New Sightings of Nagarjunasagar Racers, Platyceps bholanathi (Sharma 1976), from Tirupati, Andhra Pradesh, India
}

\author{
Viral Joshi
}

Department of Biology, Indian Institutes of Science Education and Research, Tirupati, Andhra Pradesh, India (virjoshi892@gmail.com)

$\mathrm{T}$ The Nagardunasager Racer (Platyceps bholanathi) is endemic to southern India. The species' distribution is poorly known, with few scattered records that include the type locality in the Nagarjuna Hills in Andhra Pradesh (Sharma 1976), the Sheshachalam Hills in Andhra Pradesh (Guptha et al. 2012), Nalgonda in Hyderabad (Seetharamaraju and Srinivasulu 2013), Thally in Tamil Nadu and Devarkonda in Hyderabad (Ganesh et al. 2013), Bellary in Karnataka (Sharma et al. 2013), the Gingee Hills in Tamil Nadu (Smart et al. 2014), the Rishi Valley in Andhra Pradesh (Deshwal and Becker 2017), Sigur in Tamil Nadu (Samson et al. 2017), and near the Lakshmi Narasimha Temple and in the Sanyasikundu foothills in Tamil Nadu (Melvinselvan et al. 2018).

On 25 December 2019, I encountered two road-killed Nagardunasager Racers (Fig. 1) near the Alipiri Road, Kapila Thirtham, Tirupati, Andhra Pradesh, India (13³8'50.1"N, $79^{\circ} 24^{\prime} 21.8^{\prime \prime E}$ ). The specimens have been submitted to the Sheshachalam Biodiversity Lab, Tirupati, Andhra Pradesh, India (Voucher Nos. NJS20191225-1 and NJS201912252). The identity of the specimens was confirmed by Harshil Patel.

The locality is very near a previous record listed in Guptha et al. (2012). Nevertheless, these new records of the species after eight years suggest that $P$. bholanathi might be more common in suitable habitat than previously thought. Additional surveys are necessary to better understand the distribution of this rare and endemic species.

\section{Acknowledgements}

I thank the Andhra Pradesh Forest Department and Seshachalam Lab members, Dr. Raju Vyas, and Raja Bandi, Harsha Kumar, and Dr. Robin VV for their help.
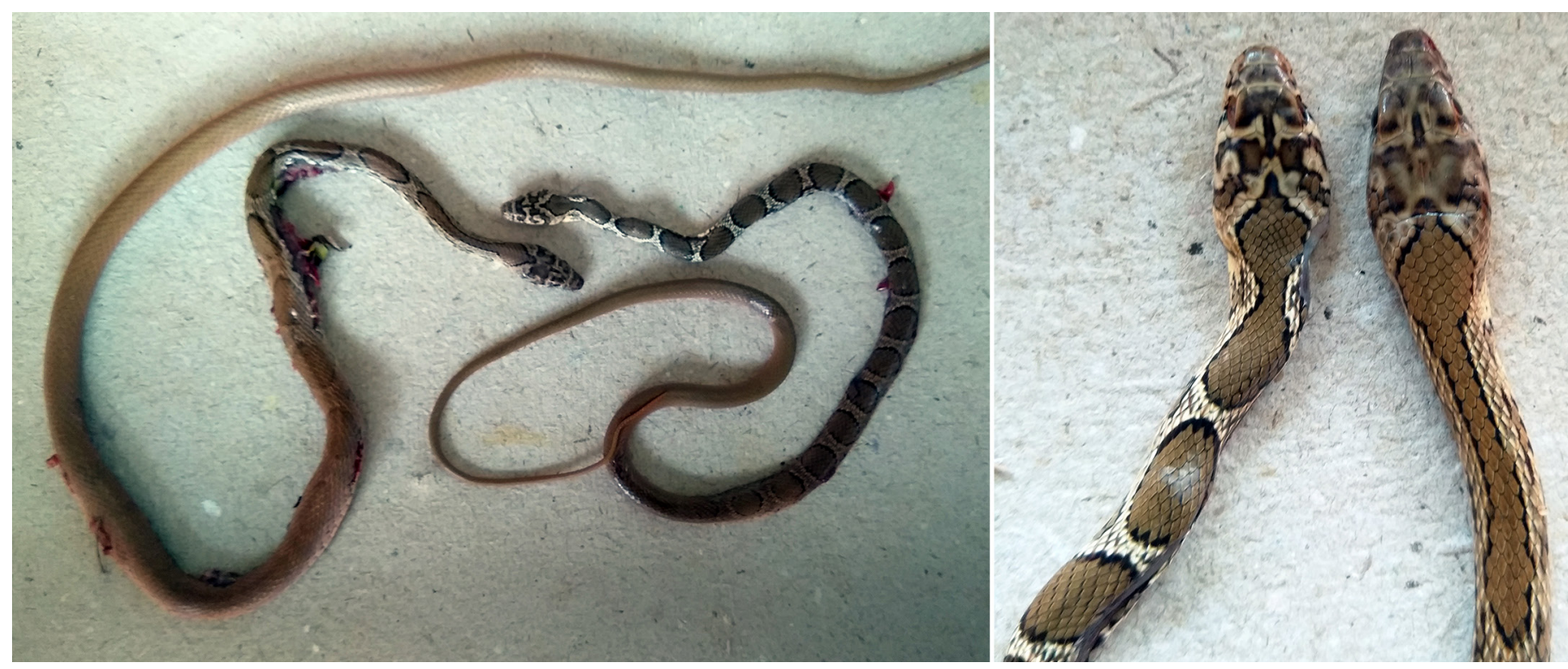

Fig. 1. Two road-killed Nagardunasager Racers (Platyceps bholanathi) from near the Alipiri Road, Kapila Thirtham, Tirupati, Andhra Pradesh, India. Photographs by the author. 


\section{Literature Cited}

Deshwal, A. and B. Becker. 2017. New locality record of Nagarjunasagar Racer (Coluber bholanathi) (Squamata: Serpentes: Colubridae) from near Rishi Valley School, Andhra Pradesh, India. Russian Journal of Herpetology 24: 245-247. DOI: 10.30906/1026-2296-2019-24-3-245-247.

Ganesh, S.R., D. Adimallaiah, and P.K. Kailash. 2013. New locality records of Nagarjun Sagar racer snake, Coluber bholanathi Sharma, 1976/Nuevos registros de localidad para la serpiente corredora Coluber bholanathi Sharma, 1976. Herpetotropicos 9: 9-12.

Guptha, B., N.V.S. Prasad, and D. Veerappan. 2012. Rediscovery and range extension of Coluber bholanathi Sharma, 1976 from Seshachalam hills, Andhra Pradesh, India. Herpetology Notes 5: 447-448.

Melvinselvan, G., D. Nibedita, P. Magesh, and K. Elambharathy. 2018. New locality records of Nagarjunsagar Racer, Platyceps bholanathi, Sharma 1976 from Tamil Nadu, Southern India. Captive \& Field Herpetology 2: 29-32.

Samson, A., P. Santhoshkumar, B. Ramakrishnan, S. Karthick, and C. Gnaneswar.
2017. New distribution record of Nagarjunasagar Racer Platyceps bholanathi (Reptilia: Squamata: Colubridae) in Sigur, Nilgiris landscape, India. Journal of Threatened Taxa 9: 10014-10017. DOI: https://doi.org/10.11609/ jott.3175.9.3.10014-10017.

Seetharamaraju, M. and C. Srinivasulu. 2013. Discovery and description of male specimen of Coluber bholanathi Sharma, 1976 (Reptilia: Colubridae) from Hyderabad. Taprobonica 5: 32-35. DOI: 10.4038/tapro.v5i1.5659.

Sharma, R. 1976. Some observation on ecology and systematics of Coluber bholanathi, a new species of snake (Reptilia: Squamata: Colubridae) from India. Comparative Physiology and Ecology 1: 105-107.

Sharma, V., J. Louies, and A. Vattam. 2013. A Contribution to Coluber bholanathi Sharma, 1976 (Serpentes: Colubridae). Russian Journal of Herpetology 20: 259-263. https://doi.org/10.30906/1026-2296-2013-20-4-259-263.

Smart, U., E.N. Smith, B.H.C.K. Murthy, and A. Mohanty. 2014. Report of Nagarjunasagar Racer Coluber bholanathi Sharma, 1976 (Squamata: Serpentes: Colubridae) from the Gingee Hills, Tamil Nadu, India. Journal of Threatened Taxa 6: 5671-5674. DOI: 10.11609/JoTT.o3628.5671-4. 